\title{
Comparison between tow techniques for induction of general anesthesia : popofol -fentanyl and ketamine fentanyl in dogs
}

\author{
O.H. Al-Hyani
}

Coll. of Vet. Med./Unive. of Mosul

\begin{abstract}
This study was conducted to evaluate the anesthetic quality between propofol-fentanyl mixture $(\mathrm{P}-\mathrm{F})(2 \mathrm{mg} / \mathrm{kg}+0.004 \mathrm{mg} / \mathrm{kg}$, i.v., respectively)and ketamine-fentanyl mixture (K-F)(10 $\mathrm{mg} / \mathrm{kg}+0.004 \mathrm{mg} / \mathrm{kg}$, i.v., respectively) in six adult dogs premedicated with atropine $(0.05 \mathrm{mg} / \mathrm{kg}$, i.m.) and xylazine $(2 \mathrm{mg} / \mathrm{kg}$, i.m.).The results revealed presence of significant difference $(\mathrm{p}<$ $0.05)$ only in the induction of anesthesia, recovery and standing period between both protocols.PF mixture produced rapid, smooth and free of excitement induction $(9.50 \pm 0.76 \mathrm{sec})$ with transit apnea $(19.16 \pm 2.4 \mathrm{sec})$. The duration of anesthesia was $(23.33 \pm 2.10 \mathrm{~min})$,narcosis $(32.50 \pm 1.70$ min) and anesthesia characterized by good muscle relaxation and abolishment of all reflexes with decrease in R.R. and increase in H R. Recovery was calm and rapid (46.6 $\pm 2.25 \mathrm{~min}$ ) and standing time was short (14.16 $\pm 1.40 \mathrm{~min})$, While anesthesia with $\mathrm{K}-\mathrm{F}$ mixture characterized by slow and rough induction $(29.16 \pm 1.53 \mathrm{sec})$, poor to moderate muscle relaxation and relatively shorter duration of anesthesia $(18.83 \pm 3.11 \mathrm{~min})$ with narcosis for about( $30.83 \pm 5.23 \mathrm{~min})$. The reflexes did not abolish completely especially eye reflexes (corneal and palpebral) and the eyes remained open. H.R. was increased but R.R. was decreased. Recovery was long and rough (78.33 \pm 4.77 $\mathrm{min})$ and stand time for $(47.50 \pm 3.09 \mathrm{~min})$.In conclusion, $(\mathrm{P}-\mathrm{F})$ mixtures produce excellent induction of general anesthesia rather than $(\mathrm{K}-\mathrm{F})$ in dogs and up to knowledge this is the first report on the uses of these mixtures for induction of anesthesia in dogs.
\end{abstract}

\section{Introduction}

The routine use of general anesthetic that has limited analgesic properties for example propofol and barbiturates and the current emphasis on prevention of post operative pain. The analgesic effect of opioids remains one of the chief reasons for their use in veterinary medicine. Opioids agents are some times used at higher doses in combination with tranquilizers such as fentanyl with fluanisone to achieve a state of profound sedation and analgesia termed neuroleptanalgesia (1). The neuroleptanalgesia can be defined as a state of central nervous system depression and analgesia produced by a neuroleptic (tranquilizer)and narcotic analgesic .The state of sedation and analgesia adequate for surgical intervention have been produced in man ,dogs and primates with a combination of the narcotic analgesic and the neuroleptic drugs (2).The neuroleptanalgesic drugs can be given in same syringe in some cases or they may be injected separately by the i.m. or i.v. route after pretreatment with atropine (1).Some research refers to use the opioids agent with anesthetic drug such as propofol with fentanyl (3). Fentanyl (opioids) is a pure $\mathrm{Mu}(\mu)$ agonist, 50-100 times more potent than morphine and has a rapid onset of action with short duration of action. It is capable of producing a high level of analgesia, sufficient to allow surgery $(4,5)$. Fentanyl in dog, rat, and primates produce sedation while in horses, mice and cats it is said to produce excitement(5). Fentanyl has been used to produce complete surgical anesthesia in dogs but its more commonly employed with the neuroleptic agent to form neuroleptanalgesic mixtures. Also it has been used as an analgesic supplement during surgical anesthesia and for post operative analgesia (6).The aim of this study was for evaluation the anesthetic properties between propofol-fentanyl and ketamine - fentanyl mixture in xylazine premedicated dogs. 


\section{Materials and Methods}

Six adult dogs from both sexes were used. The dogs had body weights ranging from $(15-20 \mathrm{~kg})$. They were housed in standard kennels and food, water was freely available. The drugs used for the study included:

1- Propofol (Diprivan, AstraZeneca , Macclesfield, UK, 1\%).

2- Ketamine hydrochloride (Ketamine BP, $50 \mathrm{mg}$, Holden, medical, Netherlands).

3- Fentanyl (Fentanyl - Janssen , 0.078 mg $/ \mathrm{ml})$.

4- Xylazine (CEVA Animal Health, France, $2 \%$ ).

5- Atropine sulphate (ADWIA, Egyptian, $1 \%)$.

The dogs were premedicated with atropine sulphate $(0.05 \mathrm{mg} / \mathrm{kg}$, i.m. $)$, followed $15 \mathrm{~min}$ latter by xylazine $(2 \mathrm{mg} / \mathrm{kg}$, i.m.). Each dog was anesthetized, $15 \mathrm{~min}$ after premedication, with propofol-fentanyl mixture (P-F) at dose $(2 \mathrm{mg} / \mathrm{kg}+0.004$ $\mathrm{mg} / \mathrm{kg}, \quad$ respectively), administered intravenously through the cephalic vein. The same dog was re-anesthetized with ketamine-fentanyl mixture (K-F) at dose (10 $\mathrm{mg} / \mathrm{kg}+0.004 \quad \mathrm{mg} / \mathrm{kg}, \quad$ respectively) administered also through the same cephalic vein 10 days latter. After induction of anesthesia, endotracheal intubation were carried out.The properties of anesthesia for both mixtures were assessed though measuring the followings:

1- The quality and time (sec) of the induction of anesthesia.

2- The quality and time of the Recovery state (Time interval (min.)between last bolus injection of drug and the dogs ability to stand ).

3- Time of Narcosis (min.), (sleep like state with varying degree of analgesia).

4- Standing time (time interval (min) between first head movement with change in posture from lateral to sternal recumbency and the $\operatorname{dog} s$ ability to stand).

5- Duration of anesthesia (time interval(min.)between abolishment of swallowing reflex until its reappearance).

6- Assessments of reflex abolishment, muscle relaxation, incidence of side effects, heart and respiratory responses (HR and RR) were considered.

The data were analyzed by in depended student- $\mathrm{T}$ test at significant difference $(\mathrm{P}<$ $0.05)$.

\section{Results}

Following premedication with atropine and xylazine, induction of anesthesia with $(\mathrm{K}-\mathrm{F})(10 \mathrm{mg} / \mathrm{kg}+0.004 \mathrm{mg} / \mathrm{kg}$, i.v. $)$ characterized by slow and rough with excitement induction $(29.16 \pm 1.53 \mathrm{sec})$. The plane of anesthesia characterized by moderate to poor muscle relaxation.Corneal and palpebral reflexes did not abolish and the eyes still open with nystagmus. The swallowing and pedal reflexes disappeared. Recovery was long and rough with excitement $(78.33 \pm 4.77 \mathrm{~min})$ and the animal consumes long time to become on the standing position(47.50 $\pm 3.09 \mathrm{~min})$. The duration of anesthesia(18.83 $\pm 3.11 \mathrm{~min}$.) and narcosis $(30.83 \pm 5.23 \mathrm{~min})$ was shorter than anesthesia with $(\mathrm{P}-\mathrm{F})(2 \mathrm{mg} / \mathrm{kg}+0.004$ $\mathrm{mg} / \mathrm{kg}, \mathrm{i} . \mathrm{v}$.)which was characterized by rapid and smooth induction $(9.50 \pm 0.76 \mathrm{sec})$ with apnea $(19.16 \pm 2.4 \mathrm{sec})$ and duration of anesthesia with narcosis for(23.33 \pm 2.10

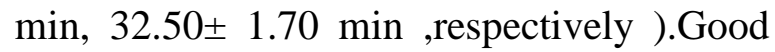
muscle relaxation was noticed in (P-F) with abolishment of all body reflexes. Recovery was rapid and smooth $(46.6 \pm 2.25 \mathrm{~min})$ and the animals were able to stand after awakened from anesthesia in short time (14.16 $\pm 1.40 \mathrm{~min})$. Both protocols lead to increase in H.R. and decrease in R.R. (Table No.1,2,3). The statistical analysis by use of students (T) test, show that induction, recovery and standing time during anesthesia with (P-F) was significantly better than (K$\mathrm{F})$ at $(\mathrm{P}<0.05)$ but not represented any 
significant difference in the duration of anesthesia and narcosis between both them.

Table 1: Summary of characteristic of anesthesia with (P-F) and (K-F) in six dogs premedicated with atropine and xylazine.

\begin{tabular}{|l|l|l|l|l|l|l|}
\hline variable & $\begin{array}{l}\text { Induction } \\
\text { time } \\
(\mathrm{sec})\end{array}$ & $\begin{array}{l}\text { Recovery } \\
\text { period } \\
(\mathrm{min})\end{array}$ & $\begin{array}{l}\text { Duration } \\
\text { of } \\
\text { anesthesia } \\
(\mathrm{min})\end{array}$ & $\begin{array}{l}\text { Narcosis } \\
(\mathrm{min})\end{array}$ & $\begin{array}{l}\text { Standing } \\
\text { time } \\
(\mathrm{min})\end{array}$ & Apnea \\
\hline $\begin{array}{l}\text { K-F } \\
\text { mixture }\end{array}$ & $\begin{array}{l}29.16 \pm \\
1.53\end{array}$ & $\begin{array}{l}78.33 \pm \\
4.77\end{array}$ & $\begin{array}{l}18.83 \pm \\
3.11\end{array}$ & $\begin{array}{l}30.83 \pm \\
5.23\end{array}$ & $47.50 \pm 3.09$ & $*$ \\
\hline $\begin{array}{l}\mathrm{P}-\mathrm{F} \\
\text { mixture }\end{array}$ & $\begin{array}{l}9.50 \pm \\
0.76\end{array}$ & $\begin{array}{l}46.6 \pm \\
2.25\end{array}$ & $\begin{array}{l}23.33 \pm \\
* *\end{array}$ & $\begin{array}{l}3.10 \\
1.50 \pm\end{array}$ & $\begin{array}{l}14.16 \pm \\
1.40 \\
* *\end{array}$ & $\begin{array}{l}19.16 \pm \\
2.4\end{array}$ \\
\hline
\end{tabular}

* Not present

** Present significant difference at $(\mathrm{P}<0.05)$

Table No. 2: Summary of the H.R. in six dogs induced with (P-F) and (K-F)

\begin{tabular}{|c|c|c|c|c|c|c|}
\hline $\begin{array}{l}\text { Time } \\
(\min )\end{array}$ & $0 \mathrm{~m}$ & $20 \mathrm{~m}$. & $40 \mathrm{~m}$. & $60 \mathrm{~m}$. & $80 \mathrm{~m}$. & $100 \mathrm{~m}$. \\
\hline $\mathrm{K}-\mathrm{F}$ & $\begin{array}{l}102.5 \pm \\
2.5\end{array}$ & $\begin{array}{l}126 \pm \\
12.62\end{array}$ & $\begin{array}{l}122 \pm \\
6.63\end{array}$ & $\begin{array}{l}115.25 \pm \\
4.89\end{array}$ & $\begin{array}{l}84 \pm \\
5.83\end{array}$ & $\begin{array}{l}83.5 \pm \\
2.06\end{array}$ \\
\hline P-F. & $\begin{array}{l}101 \pm \\
7.37\end{array}$ & $\begin{array}{ll}120.5 \quad \pm \\
19.15\end{array}$ & $\begin{array}{l}132.5 \pm \\
9.46\end{array}$ & $\begin{array}{l}124 \pm \\
12.75\end{array}$ & $\begin{array}{l}102.5 \pm \\
11.29\end{array}$ & $\begin{array}{l}93.5 \pm \\
26.47\end{array}$ \\
\hline
\end{tabular}

Table No. 3: Summary of the R.R. in six dogs induced with (P-F) and (K-F)

\begin{tabular}{|l|l|l|l|l|l|l|}
\hline $\begin{array}{l}\text { Time } \\
(\mathrm{min})\end{array}$ & $0 \mathrm{~m}$. & $20 \mathrm{~m}$. & $40 \mathrm{~m}$. & $60 \mathrm{~m}$. & $80 \mathrm{~m}$. & $100 \mathrm{~m}$. \\
\hline K-F & $21 \pm 1$ & $18 \pm 1.15$ & $22 \pm 3.8$ & $20 \pm 2.3$ & $17 \pm 2.5$ & $15 \pm 1$ \\
\hline P-F. & $26 \pm 2.4$ & $20.75 \pm 2.7$ & $14 \pm 5.3$ & $9.5 \pm 4.5$ & $8 \pm 1.4$ & $12 \pm 0.0$ \\
\hline
\end{tabular}

\section{Discusion}

Anesthesia with (P-F) leads to rapid, smooth and free of excitement induction with apnea. This effect resemble that found by $(4,7,8,9,10)$, where the induction with propofol characterized by rapid onset of action with smooth and free of excitement and transient apnea frequently followed a loading dose of propofol, in addition the fentanyl has depressed action on the respiration with rapid onset of action,while the anesthesia with (K-F) lead to slow, smoothing less induction and this is finding is an agreement with these found by (7) where induction with ketamine characterized by excitement, rough and muscle tone.The recovery from $(\mathrm{P}-\mathrm{F})$ was calm and rapid with short stand time after awakened from anesthesia rather than (K-F) where the recovery and stand time was long and rough, this is finding was resembled to these observed by $(1,11,12,7)$ who sated the propofol has lipophilic character and minimal cumulative effect where its rapidly taken up by vessels rich organs such as brain ,liver and heart then quickly redistributed to muscles and fate and 
subsequently metabolized with rapid complete recovery and free of excitement while the recovery from ketamine was long with violent convulsions. The duration of anesthesia and narcosis in (P-F) relatively was better than $(\mathrm{K}-\mathrm{F})$ in spite of the propofol has no or poor analgesic properties (13) and this may be due to the good properties of fentanyl which has high level of analgesia and capability to produce complete surgical anesthesia in dog that lead to achieve of good duration of anesthesia with good narcosis $(4,6)$.Both protocols lead to decrease in R.R. and increase in H.R. and this feature was founded by $(3,4,5,14)$ whom sated that ketamine and propofol causes respiratory depression and increase in heart rate. Also fentanyl itself cause respiratory depression in high doses and it has minimal depressed effect on cardiovascular functions.

\section{References}

1- Mckelvery D, hollingshed KW. (2003). Veterinary anesthesia and analgesia $.3{ }^{\text {rd }}$ edition. INC, Mosby, USA,PP: 43-140.

2- Soma LR (1977).Text book of veterinary anesthesia .The Williams and Wilkins Company ,Baltimore , U.S.A., PP: 131-132.

3- Hernandiez C, Parramon F, GarciaVelasco P, Vilapana J, Garcia C, Villalanga A. (1999). Comparative study of three techniques for total intervenous anesthesia:Midazolamketamine, propofol-ketamine and propofol -fentanyl.Rev Esp Anesthesiol Reanim,46:154-158.

4- Seymour CH, Gleed R. (1999). Manual of small animal anesthesia and analgesia .BSAVA, United Kingdom, PP:64-93.

5- Hall LW, Clarke KW, Trim CM.(2003). Veterinary Anesthesia, $10^{\text {th }}$ edition, W.B.Sunders Co., London ,PP:9798.

6- Hall LW, Clarke KW. (1983).Veterinary Anesthesia, $8^{\text {th }}$ edition ,Bailliere Tindall ,Philadelphia, London ,PP: 67-68.

7- IIkiw, JE. (2002). Injectable anesthetic in dogs. In: Recent Advances in Veterinary Anesthesia and analgesia Companion Animals, R.D. Gleed and J. W. Ludders (Ed.) Publisher: International Veterinary Information Service,
Ithaca, NY. (www.ivis.org) A1401.0702.

8- Mama KR (2000). Anesthetic management of the horse . In Recent advances in Anesthetic mangment of large Domestic Animals , Steffey E.P. (Ed.) international veterinary information service, Ithaca NY (www.ivis. org) A0604,1000.

9- Wanger AE, Hellyer PW(2000).Surgery of anesthesia techniques and concerns in private veterinary practice. JAVMA; 217 (11):16521657.

10- Goodman NW, Black AMS, Carter JA(1987).Some ventilatory effects of propofol as sole anesthetic agent. Br J Anaesth ; 59:1997-1503.

11- Watkins SB, Hall LW, Clarke KW(1987). Propofol as an intravenous anesthetic agent in dog's. Vet Rec ; 20: 326-29.

12- Weaver BMQ, Raptopoulos D(1990). Induction of anesthesia in dogs and cats with propofol. Vet Rec; 126: 617-620.

13- Booth $\operatorname{DM}(2007)$. Whats new in dog therapy for small animals.College Station , Texas . (www.whats new,com) ,77843-4466.

14- Tan CH,Onsiong MK(1998).Pain on injection of propofol.Anesthiology, PP:468-476. 


\section{مقارنة بين طريقتين لإحداث التخدير العام: برويوفول-فنتانيل والكيتامين-فنتانيل

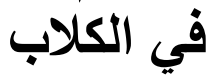 \\ كلية الطب البيطري/ حازم الحيانية الموصل

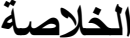

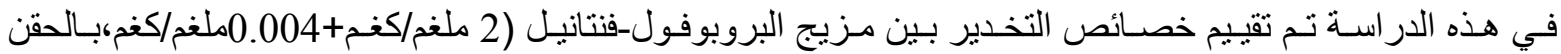

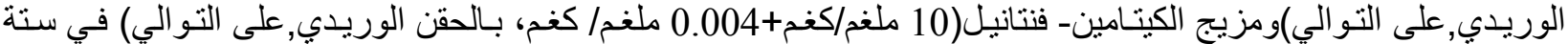

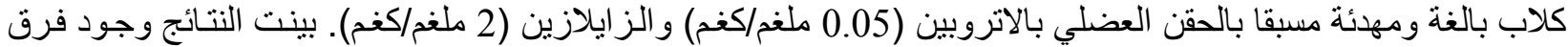

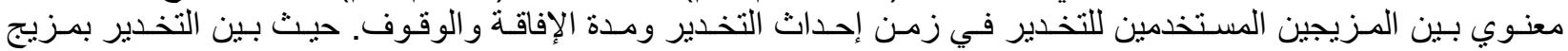

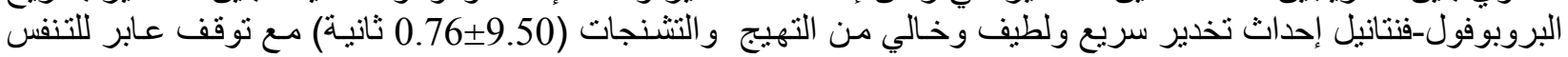

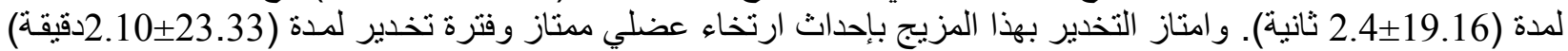

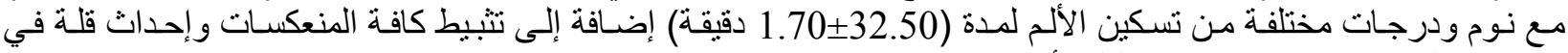

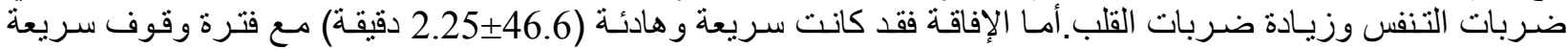

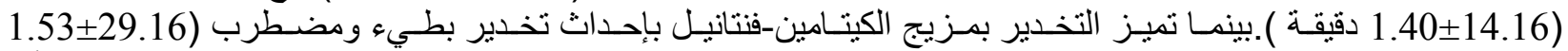

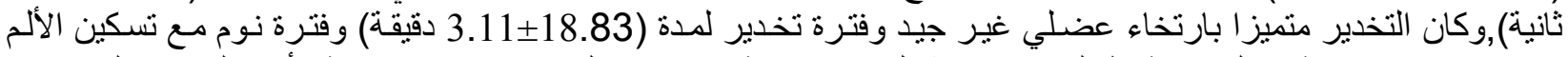

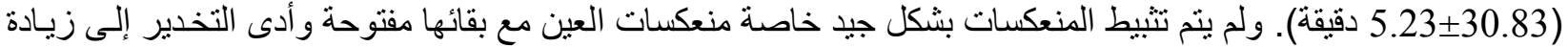

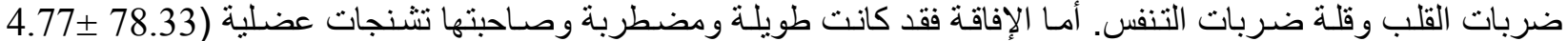

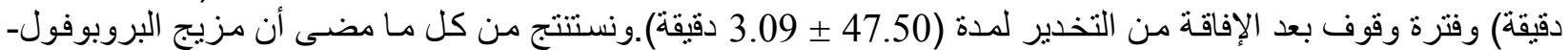

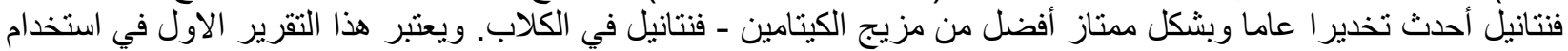
هذا المزيج للتخدير الوريدي الكامل في الكلاب. 